\title{
The factors that determine shopping centre rent in Wuhan, China
}

Abstract

Purpose- this paper investigates the factors that affect retail rent of the shopping centres in Wuhan, an important city in central China.

Design/methodology/approach-the study uses a dataset of 68 shopping centres in urban Wuhan. A regression model is constructed to estimate the impact on retail rent of a composite range of variables that would capture the physical characteristics, spatial characteristics, potential attractiveness of shopping centres and market condition.

Findings-the empirical findings suggest the ceiling height, closeness to metro line station, being situated in commercial central area, vacancy rate and income have significant impact on rental level. Unexpected, the retail mix has a significant negative impact on rent. The impact of the more determining factors found in western research - size, age, parking space and anchor tenant - is not supported in the Wuhan study.

Research limitation/implication- while 68 shopping centres are included in the test, the sample size is relatively small. The comparatively short history of retail market in Wuhan won't allow to test the rent adjustment process.

Originality/value-this is the first paper to investigate retail rent determinants in a second-tier city in China. The results of the study give designers, developers and investors critical insights into the determinants of retail rent in an emerging market.

Keywords: retail rent, shopping centre, regression modelling, Wuhan, China

Paper type: research paper 


\section{1. introduction}

The concept of "shopping mall" was firstly introduced in the U.S and its primary function - the provision of a wider range of goods and services to shoppers in units with far larger unit footprints than individual department store (Tay et al., 1999)- remains unchanged. The first suburban enclosed shopping centre, the Southdale Center, opened near Minneapolis in the U.S in 1956 and became the template for subsequent centres across North America and Western Europe. The success of these malls has been underpinned by the expansion of the car ownership, improvement to transportation infrastructure and residential decentralization. The shopping centres, especially out-of-town shopping centres dominated the retail landscape in these countries for decades and have been regarded as the most successful land use, real estate and retail business concept of the twentieth century (Beyard and O'Mara, 1999).

While the purpose-built shopping centre has become an established feature on the retail landscape in Western economies, in China the dedicated shopping centre is a relatively recent innovation and has become a driver of change in retailing patterns. China did not have real shopping centres until the mid-1990s. The first wave of retail development began in the largest cities of Beijing, Shanghai, Guangzhou and Shenzhen and was supported by central government's policy designed to open its retail market in six largest cities and five special economic zones (SEZs) to foreign retailers and investors as a strategy to accelerate the country's tertiary industry growth, and create more job opportunities (Lam, 1995; Shi and Yang, 1998). While the Chinese government encouraged foreign retail investment through joint venture with a Chinese company, only 18 joint venture retail enterprises were approved by the central government by the end of 1997, in large part due to the underlying stringent control of a JV establishment. However, many municipal governments enthusiastically welcomed direct foreign investment in large shopping centres to help raise the profile of their cities.

In contrast to the booming in shopping centre investment and development, the reseach on China's shopping centre rent is scant, especially there is no empirical research of retail property rent in the second tier cities of China. This paper will focus on investigation of the factors that influence retail rents in Wuhan, the capital of Hubei province with the largest pupolation in central China. As the largest city and transportation hub in central China, Wuhan plays an important role in connecting to the other regions of China. Benefiting from the robust economic growth over the last two decades, the living standard of local residents has improved greatly. According to a research report by Knight Frank (2011), 95\% of shopping centres in Wuhan were opened in last two decades as a result of rapid economic growth and robust comsumer expenditure. The shopping centre has proved to 
be a powerful catalyst of urbanization in China and the trend will continue in a long term (Zheng and Liu, 2003).

Hence, the study of the determinants of shopping centre rents in Wuhan provides more comprehensive understanding of the commercial property market in Wuhan for developers and investors who can assess the impact of drawing power, physical features and locational features of retail property on the level of retail rent charged to the tenants. In this paper, the retail rents of 68 shopping centres and department stores in major Wuhan districts are analysed. To the best of our knowledge, this is the first detailed study of retail rent performance in one of the most important and fast expanding second tier cities in China with the aim to improve the understanding of the commercial real estate market in China's second tier cities which will become the focal point of investment in the near future.

The paper is organized as follows. Chapter 2 reviews the literature, followed by the introduction of city background in Chapter 3. The data definition and research methodology are discussed in Chapter 4. The results are analysed in Chapter 5. Chapter 6 draws the conclusions of the research.

\section{Literature review}

The published empirical research considering the determinants of shopping centre rent levels has been centred on the developed western countries such as the United States, the United Kingdom and Australia (e.g. Benjamin et al., 1990; Benjamin et al., 1992; Mejia and Benjamin, 2002; Des Rosiers et al., 2005; Hanna et al., 2007; Yuo et al., 2011; Vernon, 2012). Most of these studies are grounded in the established theoretical foundation of central place theory, agglomeration and demand-externality to examine the impact of characteristics and location of the retail property on the levels of retail rent achieved. The studies povide considerable insights into the mechanics of rental price determination. For example, Sirmans and Guidry (1993) studied the determinants of retail rents for shopping centers in Baton Rouge, Louisiana and found that the ability of a shopping centre to draw customers is one of the foremost determinants on rentals. The customer drawing power mainly comprises shopping centre size, age, ceiling height, retail mix, anchor tenants and so forth. It is argued that large shopping centre normally has better image and is expected to attract more customers due to its large retail space, which is more competitive than a small one. For example, Des Rosiers et al. (2005) suggested that the space agglomeration of large centre is relatively sufficient to meet consumers' multiple needs due to its product diversity. Gatzlaff et al. (1994) also stated that it is easier for large shopping centres to form spatial concentration of tenants and shoppers, bringing more retail sales, thus extracting higher rentals from tenants. Compared to 
small stores, shoppers are more willing to choose large centres as their destination and spend more time there (Kirkup and Rafiq, 1994).

Tay et al. (1999) assert that shopping centre's styles have changed over time and the age of a shopping centre inversely affects the rents charged to retailers. Compared to newer centres, older ones suffer from a series of problems, such as inappropriate tenant mix, physical neglect, as well as older facilities. As a consequence, when facing with strong competition from newer shopping centres, older ones have to lower the rental levels to retain tenants (Benjamin et al., 1990). A similar research of Sirmans and Guidry (1993) concludes that older shopping centres need more daily maintenance, therefore taking an adverse effect on tenants that have signed leasing contracts. However, the older centres may have certain advantages of customer awareness and loyalty, thus new opened centres have to lower rentals to attract tenants.

The issue of shopping centre's desing and configuration has been considered within the literature. Hui et al. (2007) studied retail rent of 151 retail facilities in Hong Kong and found that shopping centres with taller ceiling height can draw more attention from shoppers. In such a shopping centre, customers feel more comfortable and would like to stay longer and spend more there, which could potentially motivate property owners to raise the rent. Vernon (2012) discovered that architectural design or configuration is another key factor in determining shopping centre rents. In western countries, the mainstream configurations of shopping centres consist of mall, cluster, L-shape, Ushape, as well as linear-shape (Sirmans and Guidry, 1993; Brown, 1999). The enclosed mall, as the most functional designing style, offers a wider range of services and goods, including entertainment, dining, leisure, et al than common stores. Hence, the rents charged by malls are expected to be higher than that of other configurations. The cluster centre can be defined as a department store surrounded by a group of small retailers (O'Roarty et al, 1998). As it has relatively poor shopping environment, the rent in cluster centre is normally lower than that in malls. Both L-shaped and Ushaped configurations are designed to restrict the centres' length and face public parking space, however, as such layouts affect consumers' walking path and tenants' visibility to people (Mejia and Benjamin, 2002), these studies indicated that L-shaped and U-shaped centres have lower rentals compared to malls and clusters.

Other fruitful areas of the reserch have been in shopping centre's location and accessibility. Des Rosiers et al. (2005) observed that location has been playing a significant role in rent setting process, especially for retail space. The overall level of rents charged by a shopping centre will depend on its location relative to other competitors or regional markets. Locational elements that include 'sitespecific physical' and 'geographically linked locational' characteristics largely contribute to the value 
of shopping centres (Forgey and Goebel, 1995). Tay et al. (1999) suggested the centres situated at desirable sites have higher rental premiums. Mejia and Benjamin (2002) further emphasized a highly visible and easily accessible site is fairly essential for shoppers. The better the accessibility, the bigger the success achieved by landlords and tenants, while other factors remain unchanged.

Some studies also assert that rentals are normally expected to be high where there is dense population, big traffic count and high visibility. To be specific, when shopping centres are built in neighbourhood or near residence, especially with high income and purchasing power, they will attract a big volume of consumers daily and thus increase sales; when these centres are located nearby metro entrances, bus stations, train stations or other transports, the great traffic flow will bring them with more successful opportunities (Hui et al., 2007). Des Rosiers et al. (2005) stated that high shopper traffic level is a prerequisite to the success of a shopping centre. When the centres are highly visible, especially located on main roads or intersections, shoppers travelling on adjacent roadways can easily reach there. According to Ordway et al. (1988), satisfying visibility performs positively to lower vacancy. In addition, Harris and Ullman (1945) argued that shopping centres located at traditional trade areas are more likely to have high rentals than other new business districts. Therefore, compared to other locations, the landlords of shopping centres located in desirable sites have bigger bargaining power in rent setting process than tenants.

At a macro level, the rental levels in shopping centres can be influenced by market conditions such as economic development, rate of local employment, size of disposal income, vacancy rate, supply and demand (Ibanez and Pennington-Cross, 2013; Hendershott et al., 2002). For example, Miceli et al. (1998) found that based on diversified economy developments, the rents of shopping centres vary in different districts. The areas with high GDP or retail sales normally command higher rental rates than those with low GDP level. Vacancy rate is another key determinant on shopping centre rents. Due to increasingly deteriorated economic conditions, the business in the shopping centre is becoming more difficult to run, and lots of retailers have to move out of there, thus leaving a huge vacant space. As a consequence, landlords have to lower rents to retain those remaining tenants (Eppli and Benjamin, 1994). In commercial property market, although the supply is relatively fixed in a short term, if the supply exceeds market demand, the rent will potentially decrease; in turn, if the demand is larger than market supply, the rent will rise.

So far, there is only one paper examining the determinants of shopping centre's rent in China by Liang and Wilhelmsson (2011). They used hedonic model to test the factors that affect the rent of retail properties in Shanghai and found that the age, retail space, the distance to Jing An CBD centre and retail type have significant explanatory power in explaining the retail rents. 


\section{Background of the study city}

Wuhan is the capital of Hubei Province, China. Situated at the confluence of Yang-tze River and Han River, Wuhan has developed as a major transportation hub within Central China and remains an important location within the national strategy of the "Rise of Central China". The total area of the city is over $80 \mathrm{~km}^{2}$, of which the lake is covering an area of $33 \mathrm{~km}^{2}(41 \%)$. Geographically, Wuhan is the amalgamation of three sub-cities - Hankou, Wuchang and Hanyang - each with defined central business districts and the larger sub-cities supports a resident population in excess of 10 million (see Figure 1). Since 1990s, Wuhan's local economy has benefitted from favourable state-endorsed economic policies and a stable political landscape. This has resulted in its GDP growing by $15 \%$ per annum since the early 2000s (see Figure 2). In 2013, Wuhan's GDP was over RMB 900 billion, approaching nearly $40 \%$ of the GDP for the whole of the Hubei province. As a consequence, Wuhan is the ninth largest urban economy in China.

Figure 1: the major retail clusters of Wuhan

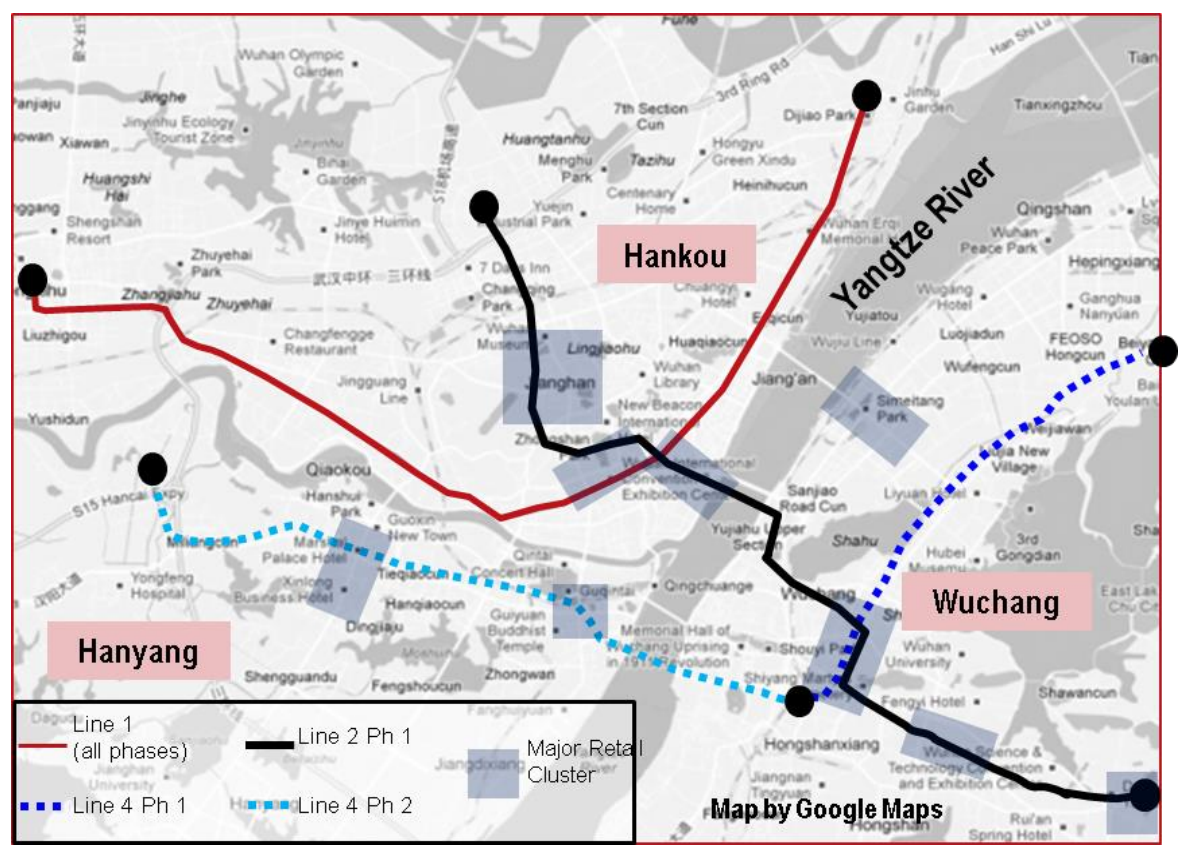

Source: compiled by the authors

Figure 2: Wuhan GDP 


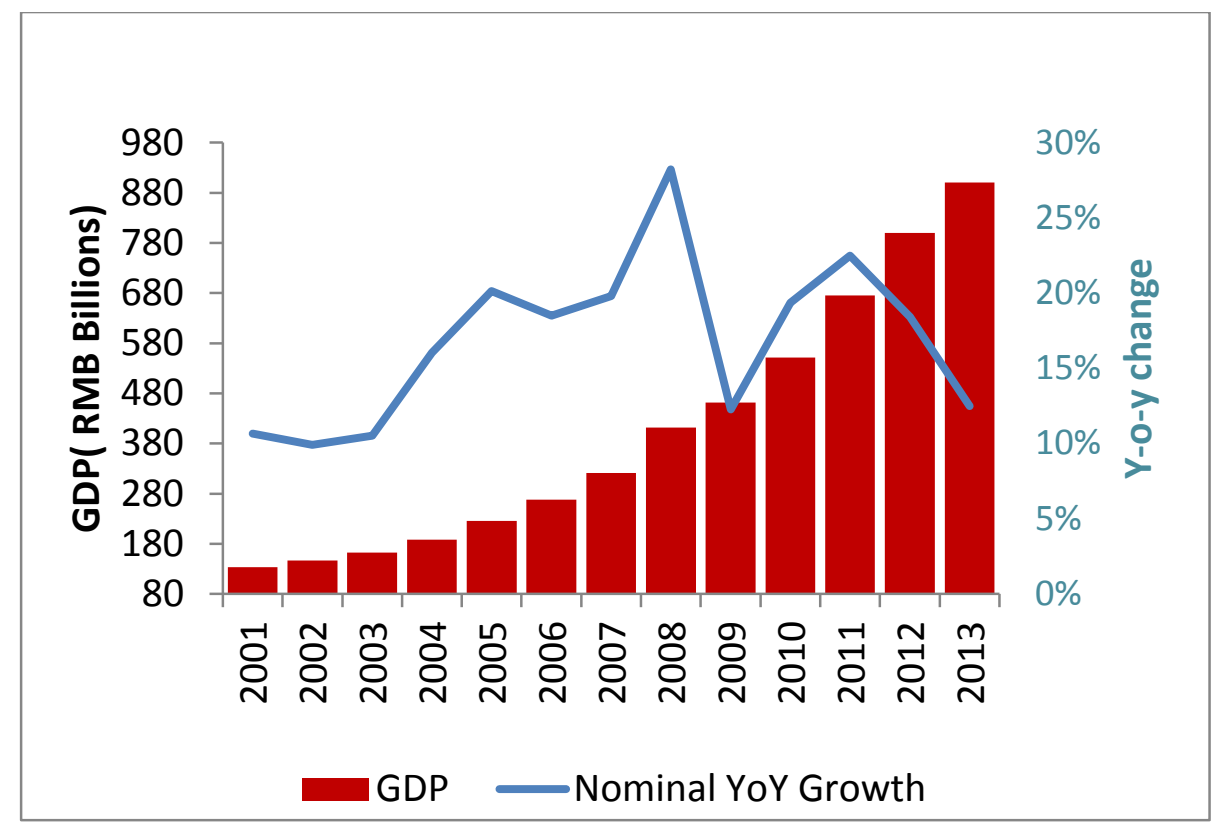

Source: Wuhan Statistical Yearbook, 2013

Figure 3: Retail sales and income in Wuhan

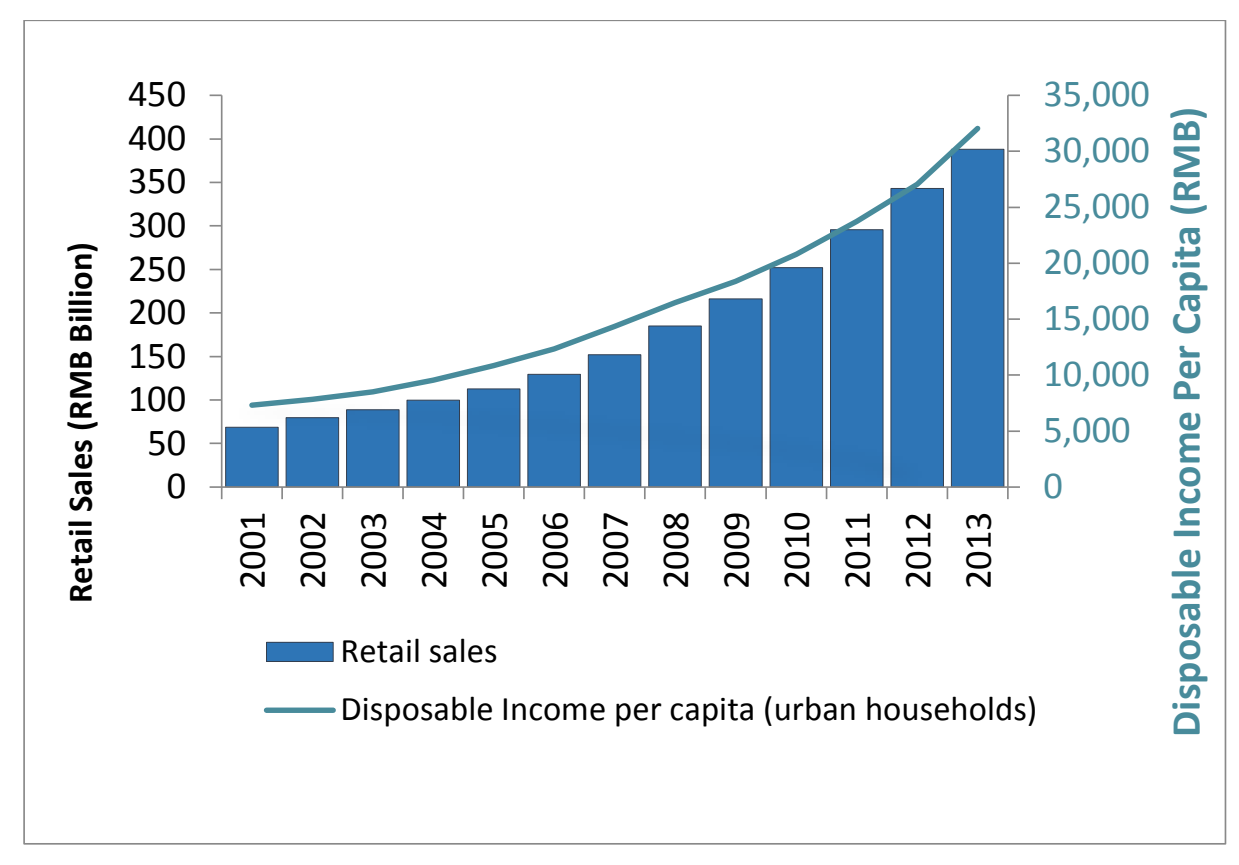

Source: Wuhan Statistical Yearbook, 2013

The success of city's economy has seen the disposable income per capita exceed RMB 30,000 per annum, an increase of $13 \%$ every year (see Figure 3). This has translated in retail sales growth of $14 \%$ per annum since 2001 and exceeded RMB388 billion in 2013. The strong performance of local economy and the sustained growth in retail sales has encouraged further retail investment and shopping centre development programmes. Since mid-1990s, 95 shopping centres, including 
department stores and shopping malls, have been developed in Wuhan's urban area with 62 of them in the central business districts of the three sub-cities and the remaining ones located in economic development zones of Hanyang and Wuchang (see Figure 1). These developments have raised the gross floorspace by over 3 million square meters (DTZ, 2014). It is estimated that the total stock of retail space would reach the peak in 2015 with a total stock of 6.6 million square meters (JLL, 2014).

Most of shopping centres in Wuhan are chain stores and were developed by the local developers and the developers from Hong Kong. What is more, many diverse shopping centres are actually owned and managed by one group, such as Wuhan Department Store Group owning five department stores and shopping malls and Langold Property Group owning five shopping malls. The other new shopping centres were developed by small developers. The retail rents for these shopping centres, shopping malls and department stores have been increasing all the way. Figure 4 displays the trend of retail rents in Wuhan.

Figure 4. Retail rent index

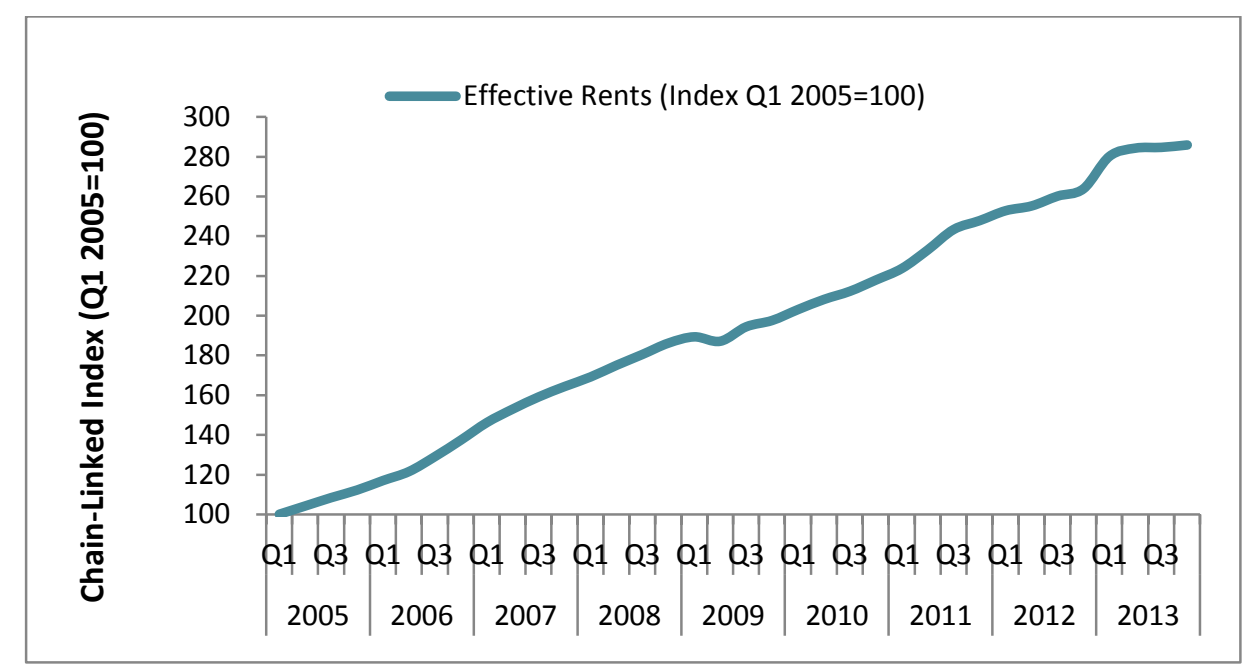

Source: JLL, Wuhan office

\section{Methodology and data}

The retail property data is collated from the market intelligence reports produced at Jones Lang Lasalle's Wuhan office. The main reporting characteristics include asking rent, location, age, gross floor area (GFA), parking space, parking fee, ceiling height, vacancy rate, anchor tenant, and retail mix. Additional data have been compiled from the official websites of the shopping centres in the study and include aspects such as the administration district where a shopping centre is located, the physical configuration of shopping centre, local disposable income, and population density. 68 shopping centres are selected from a total number of 95 shopping centres by excluding those currently under construction, not opened yet or those not located in urban areas. It should be 
noted that the retail shops and smaller-scaled malls, usually located in residential estates or mixed in the residential buildings, i.e. the secondary location, are not the subject of the study.

The following model is constructed to test the determinants of the rents for shopping centre. It is written as:

$$
\text { LnRent }=\beta_{0}+\beta_{1 i} \text { Phys }+\beta_{2 i} \text { Spat }+\beta_{3 i} M k t+\beta_{4 i} A t t r+\varepsilon,
$$

Where Phys, Spat, Mkt and Attr are vectors of property physical characteristics, spatial characteristics, market characteristics, and potential attraction characteristics respectively. $B_{0}-\beta_{4}$ denote vectors of respective regression coefficients and $\varepsilon$ is the error term.

The physical property characteristics are such as age, size, ceiling height, the shapes (e.g. L-shape or U-shape) and parking space. The spatial characteristics include the distance to metro line station, whether the shopping centres being situated on a main road, in a prime commercial centre, or surrounded by dense residence. The market factors are vacancy rate and income per capita. The potential attraction characteristics a shopping centre has are represented by such factors as anchor tenant and retail mix. The "Phys" and "Spat" can be regarded as the "endogenous attributes" of shopping centres while the "Mkt" and "Attr" are the "exogenous dimensions" (Des Rosiers et al., 2005).

We now restructure the equation (1) as the following one which includes a final model that consists of a combination of 14 variables.

$$
\begin{aligned}
\text { LnRENT }=\alpha_{0} & +\beta_{1}(\text { AGE })+\beta_{2}(\text { LnGFA })+\beta_{3}(\text { CHEIGHT })+\beta_{4}(\text { LSHAPE })+\beta_{5}(\text { USHAPE }) \\
& +\beta_{6}(\text { PSPACE })+\beta_{7}(\text { METRO })+\beta_{8}(\text { MAINROAD })+\beta_{8}(\text { RESIDENCE }) \\
& +\beta_{10}(\text { CENTRAL })+\beta_{11}(\text { ANCHOR })+\beta_{12}(\text { RETAILMIX })+\beta_{13}(\text { VRATE }) \\
& +\beta_{14}(\text { INCOME })+\varepsilon_{i}
\end{aligned}
$$

Where:

LnRENT is the logarithm form of average retail rent of ground floor for the shopping centres in the study at Q4 2013. Such rent is commonly regarded as the highest rent for the shopping centre and could better reflect its real retail value (Pashigan and Gould, 1998). Furthermore, the rent of ground floor is more sensitive to the market changes, thus helping to explore the determinants of shopping centre rents.

AGE is the age of a shopping centre. Prior research indicates that, compared to newer centres, older ones have a series of problems, such as inappropriate tenant mix, physical neglect, and frequent 
maintenance, as well as older facilities, therefore have lower rent (Benjamin et al. 1990). So it is expected to have a negative sign.

GFA is the logarithm form of gross floor area as a proxy of size. A shopping centre with larger floor area makes a better first impression on consumers than that with smaller one and provides a wider selection of goods for shoppers, thus having stronger customer drawing power. It is expected to have positive effect on the rent.

CHEIGHT is ceiling height. A shopping centre with higher ceiling height can draw more attention from people and consumers feel more enjoyable in such shopping environment and would like to stay longer (Des Rosiers et al., 2005). Thus, the ceiling height is expected to be positively related to the rent.

LSHAPED is L-Shaped centre. It is not "aesthetically pleasing" like mall or cluster configurations (Sirmans and Guidry, 1993) and potentially reduces retailer's visibility to shoppers. Therefore, the rents for L-Shaped centre should be lower than those for malls and cluster centres. It is a dummy variable. If the shopping centre is L-shaped, it takes the value of 1 , otherwise 0 .

USHAPED is U-Shaped centre. It has similar limitations to the L-Shaped centre, thus, it is expected that U-Shaped centre has lower rent than malls and cluster centres as well. It is a dummy variable. If the shopping centre is U-shaped, it takes the value of 1 , otherwise 0 .

PSPACE is car parking space a shopping centre has. Tay et al. (1999) argued that, by providing sufficient parking space for shoppers, the shopping centre's accessibility may also be increased. Therefore, it is anticipated that the parking space has a positive coefficient.

METRO is a dummy variable. If a shopping centre is situated within 5-minute walking distance to a metro line station, it equals 1 , otherwise, it is 0 . Shopping centres with short distances or direct access to metro lines are expected to be more appealing and thus will charge higher rents from tenants. It is expected to have a positive sign.

MAINROAD is a dummy variable. If a shopping centre is situated on a main road, it takes the value of 1 ; otherwise 0 . It is expected to have a positive sign, since being situated on a main road means more traffic flow than a sideway (O'Roarty et al., 1997).

RESIDENCE is a dummy variable. If a shopping centre is located in a residential area, it equals 1; otherwise it is 0 . The shopping centre located in residential area or neighbourhood would provide the goods that a household needs regularly, therefore, it is a desirable facility. It is expected to have a positive sign. 
CENTRAL is a dummy variable. It takes the value of 1 if a shopping centre is located in prime commercial centre or traditional commercial centre; otherwise 0 . To some extent, compared to suburban commercial areas, prime or central commercial clusters have some irreplaceable advantages, such as customer loyalty and economy agglomeration (Benjamin et al., 1992). Thus, it is expected to have a positive sign.

ANCHOR is anchor tenants, such as supermarket (e.g Wal-Mart. Tesco, Carrefour), large department store, famous fast-food restaurants (e.g KFC, McDonald). The presence of anchor tenant is expected to obtain high sales volume because of their popularities (Sirmans and Guidry, 1993; Benjamin et al., 1992). It is a dummy variable. A shopping centre with an anchor tenant equals 1 ; otherwise 0 . It is expected to have a positive sign.

RETAILMIX refers to a combination of retail stores that occupy space in a shopping centre. It is a dummy variable and takes the value of 1 if a shopping centre has diverse retail mix such as fashion stores, shoe stores, jewellery and other luxury goods, supermarket, restaurants, café, entertainment, cinema, otherwise it is 0 . Forgey and Goebel (1995) suggested that retail variety is a significant factor in boosting sales and desirable retail mix will contribute to the synergies within the centre. Therefore, retail mix is supposed to be positively related to the rent level.

VRATE is vacancy rate a shopping centre has and expected to have negative sign.

INCOME is annual disposable income per capita. Higher income means higher retail sales which would increase the demand for retail space and drive up retail rent, so it is expected to have a positive sign.

\section{Results}

Table 1 gives an overview of the descriptive statistics of all the variables, whereas correlations are reported in table 2 . 
Table 1: descriptive statistics test

\begin{tabular}{lcccc}
\hline Variables & Mean & Std. Deviation & Minimum & Maximum \\
\hline RENT & 16.48 & 4.83 & 6.67 & 31.00 \\
AGE & 5.27 & 4.73 & 0.08 & 19.56 \\
GFA (million sq.m) & 7.17 & 5.45 & 0.48 & 27.000 \\
PSPACE (sq.m) & 826.37 & 875.93 & - & $3,600.00$ \\
CHEIGHT (m) & 4.76 & 0.85 & 3.40 & 6.50 \\
LSHAPED & 0.04 & 0.21 & - & 1.00 \\
USHAPED & 0.07 & 0.26 & - & 1.00 \\
METRO & 0.41 & 0.50 & - & 1.00 \\
MAINROAD & 0.71 & 0.46 & - & 1.00 \\
CENTRAL & 0.24 & 0.43 & - & 1.00 \\
RESIDENCE & 0.59 & 0.50 & - & 1.00 \\
ANCHOR & 0.65 & 0.48 & - & 1.00 \\
RETAILMIX & 0.50 & 0.50 & - & 1.00 \\
VRATE (\%) & 6.65 & 10.49 & - & 54.00 \\
INCOME (RMB) & $32,951.57$ & $2,410.88$ & $23,324.00$ & $35,867.00$ \\
\hline
\end{tabular}

The typical ground floor rent is RMB 16.5 per month per sq. m, ranging from RMB 6.67 to RMB 31 . The average total gross floor area (GFA) is about 7.2 million sq. m, whilst the largest one has 27 million sq. $\mathrm{m}$ and the smallest one is only $0.48 \mathrm{sq} . \mathrm{m}$. The average ceiling height is about 4.76 meter, the highest one is 6.5 meter and lowest one is 3.4 meter. The average age of shopping centres is 5.3 years ranging from 1 to 20 years. 59\% of the shopping centres are located in dense residential areas and $24 \%$ are located in central commercial area. $71 \%$ of them are situated on a main road. $41 \%$ of shopping centres/department stores are within 5 minutes walking distance to metro line entrances. Vacancy rate is $6.6 \%$, ranging from as low as zero to as high as over $50 \%$. Over $65 \%$ of shopping centres have anchor tenants to attract consumers and 50\% shopping centres have relatively affluent retail mix, including clothing, shoes, dining, entertainment, jewellery and other luxury goods.

Table 2 reports the correlation tests of the study variables. The significant correlations of LnGFA to ANCHOR and RETAILMIX demonstrate the presence of anchor tenants in larger shopping centres with a diverse retail mix. Large shopping centres usually have larger car parking space. The significant correlations of CENTRAL to AGE, METRO and VRATE suggest that the shopping centres located in prime commercial centre or traditional commercial centre are older properties, within 5 minutes walking distance to metro line stations and have lower vacancy rate.

The regression test results are shown in table 3 . Table3 A presents the test results of 14 study variables. In table3B, two slope dummy variables (RExPS standing for the parking space of shopping centres in dense residential area and CExPS for the parking space in commercial centre area) are 
included to replace PSPACE to examine the impact of parking space on rent in different locational categories. The results in table $3 \mathrm{~A}$ and $\mathrm{B}$ are broadly the same with the same directions and significance level.

CHEIGHT is the only property physical characteristics that has significant impact on rent and has the expected sign. AGE and LnGFA as proxy of size have the expected signs, though insignificant. Most of the shopping centres in Wuhan were built in the past decade and the average building age is about 5 years, the shorter age may explain the weak explanatory power of this variable. The coefficients of the design of shopping centre proxied by L-shape or U-shape are not significant. Unexpectedly, the parking space is negatively related to rent, but insignificant. The coefficients of two slope dummies in table3B are not significant too, though the parking space of shopping centres in residential area (RExPS) has negative sign and the one in commercial centre (CExPS) has positive sign. The shopping centres in Wuhan are either located in the city /district centres or in dense residential area. The public transport is more widely used than private cars by shoppers since there are less people owning private cars. This result is further supported by the significant and positive coefficient of METRO, indicating that the closer to metro-line station a shopping centre is, the higher the retail rent of the shopping centre tends to be. At the same time, the shopping centres in prime commercial area have significantly higher rent compared to the ones located in dense residential area. Another spatial factor i.e. MAINROAD, has expected sign, but insignificant, meaning the shopping centre being situated on a mainroad doesn't necessarily have significantly higher rent.

Anchor tenant as one of the potential drawing power has no significant impact on rent, though it has expected sign. Unexpectedly, the shopping centre with a variety of tenant mix has significantly lower rent. This is different from the studies of shopping centres in the U.S and Hong Kong. One of the reasons is probably that most of these shopping centres in Wuhan are geographically closely clustered in their own submarkets. For example, Hankou Jiefang Rd cluster, Hankou Qingnian Ave cluster, Wuchang Wuluo Rd cluster, and Hanyang Wangjiawan cluster. These retailers can supplement each other to form agglomeration economies to address customers' multipurpose; therefore, to some extent, this spatial proximity feature weakens the attractiveness of retail mix for the shopping centre. In the end, the two market factors-income and vacancy rate - are both significant and have expected signs. 
Table3. Summary of the regression test

\begin{tabular}{llllllllll}
\hline & \multicolumn{3}{c}{$\mathrm{A}$} & \multicolumn{7}{c}{ Bnstandardized } \\
& $\begin{array}{l}\text { Unstandardized } \\
\text { B Coefficients }\end{array}$ & $t$ & Sig. & VIF & B Coefficients & $t$ & Sig. & VIF \\
\hline (Constant) & -14.75 & -2.66 & 0.01 & & -12.94 & -2.37 & 0.02 & \\
LNGFA & 0.00 & 1.21 & 0.23 & 2.39 & 0.00 & 0.64 & 0.52 & 2.15 \\
AGE & -0.08 & -0.91 & 0.37 & 1.78 & -0.06 & -0.76 & 0.45 & 1.70 \\
LSHAPED & -0.68 & -0.43 & 0.67 & 1.26 & -0.77 & -0.49 & 0.63 & 1.26 \\
USHAPED & 0.28 & 0.23 & 0.82 & 1.16 & 0.31 & 0.27 & 0.79 & 1.10 \\
CHEIGHT & 2.95 & 6.56 & 0.00 & 1.73 & 2.88 & 6.44 & 0.00 & 1.75 \\
PSPACE & 0.00 & -0.39 & 0.70 & 2.92 & & & & \\
VRATE & -0.06 & -1.89 & 0.06 & 1.48 & -0.06 & -1.92 & 0.06 & 1.34 \\
METRO & 2.23 & 2.88 & 0.01 & 1.73 & 2.02 & 2.60 & 0.01 & 1.79 \\
MAINROAD & 0.48 & 0.64 & 0.52 & 1.37 & 0.49 & 0.67 & 0.51 & 1.34 \\
CENTRAL & 1.90 & 1.96 & 0.06 & 2.01 & 1.20 & 1.11 & 0.27 & 2.54 \\
RESIDENCE & 0.84 & 1.08 & 0.29 & 1.75 & 1.28 & 1.37 & 0.18 & 2.56 \\
ANCHOR & 0.64 & 0.88 & 0.38 & 1.46 & 0.73 & 1.00 & 0.32 & 1.48 \\
RETAILMIX & -1.57 & -2.16 & 0.04 & 1.57 & -1.47 & -2.03 & 0.05 & 1.58 \\
INCOME & 0.00 & 3.00 & 0.00 & 1.73 & 0.00 & 2.83 & 0.01 & 1.61 \\
REXPS & & & & & 0.00 & -0.75 & 0.46 & 2.41 \\
CEXPS & & & & & 0.00 & 1.46 & 0.15 & 2.28 \\
\hline
\end{tabular}

Note: dependent variable is the natural logarithm of unit price of rent per month. Adjusted $\mathrm{R}^{2}=$ 0.763 (0.75 for table3B). F-value $=16.38$ (12.95 for table3B) and the significance level is 0.001 . Variance inflation factor (VIF) values-multicollinearity test are all lower than the threshold value of 4. Durbin-Watson value is 1.89 (1.98 for table3B), within the interval between -2 and 2 and there is no heteroscedasticity.

\section{Conclusions}

The shopping centres/malls in China are predominantly located in the city centre district or in dense residential area, unlike those in the Western countries such as the U.S. the U.K. and Canada; few are located in out-of-town location. Despite the increasing affluence of the local residence population, private car ownership is not at the levels experienced elsewhere in the wealthy western countries. Besides, due to the difference from the developed Western countries in terms of the culture, the stage of the local economy development, the level of local people's living standard and shopping habit and patterns, the factors that affect the retail rents in China may be different from the ones in these western countries as identified in the prior studies. This paper attempts to provide some empirical evidence in this aspect in order to improve the understanding of the retail property performance in China.

This paper studies the determinants of shopping centre rent in Wuhan, an important economic and commercial hub located in central China. The results of the empirical tests suggest that the factors 
that might be expected to drive rents in the Western countries do not apply to Wuhan, nor possibly in other second tier Chinese cities. The factors such as ceiling height, proximity to transport hubsmetro line stations, those within commercial central areas and the prevailing market conditions have a significant influence upon the levels of retail rent just as in the Western countries. In contrast, the factors that affect the retail rents in mature western markets such as size, parking space, age, the design of buildings and the existence of anchor tenants and retail mix do not have similar impact on retail rents in Wuhan. The test results suggest that the location and market conditions of the supply proxied by vacancy rate and demand proxied by income are most significant factors affecting retail rents. The impact of drawing power factors is weak compared with the retail market in western countries.

The findings are useful for developers and investors who may wish to better understand the performance of retail property sector and to identify the key factors that drive retail rent in a second tier Chinese city. This is likely to be of importance to international investors looking to take positions in the emerging markets of China. But the results should be treated with caution due to relatively

small sample size.There are more shops and smaller-scaled malls located in secondary location or mixed in residential estate. These retail properties are usually owned by private person or small retailers, poorly managed and have high vacancy due to less supply restriction, especially in residential estate area. But these retail properties are not included in the study. The short history of retail property market in Wuhan does not currently allow for testing the rent adjustment process. As the market matures and local shoppers become more sophisticated, the retail rents determination factors identified in the study may vary in the future.

Reference

Benjamin, J. D., Boyle, G. W. and Sirmans, C. F. (1990), "Retail leasing: the determinants of shopping centre rents", Journal of the American Real Estate and Urban Economics Association, Vol. No. 3, pp.302-312.

Benjamin, J. D., Boyle, G. W. and Sirmans, C. F. (1992), "Price discrimination in shopping centre leases", Journal of Urban Economics, Vol.32, No.3, pp. 299-317.

Beyard, M. D. and O'Mara, W. P (1999), Shopping Center Development Handbook. Third edition Washington, DC.: Urban Land Institute.

Brown, S. (1992), "Tenant mix, tenant placement and shopper behaviour in a planned shopping center", The Services and Industrial Journal, Vol. 12, No.3, pp. $384-403$.

Brown, G. M. (1999), "Design and Value: Spatial Form and the Economic Failure of a Mall”, Journal of Real Estate Research, Vol.17, No. 2, pp. 189-225. 
Des Rosiers, F. D., Theriault, M. and Menetrier, L. (2005), "Spatial versus non - spatial determinant of shopping centers rents: modelling location and neighbourhood - related factors", Journal of Real Estate Research, Vol. 27, No. 3, pp. $294-314$.

DTZ (2014) Property Times. Wuhan: DTZ Research. available at: www.dtz.com.

Eppli, M. J. and Benjamin, J. D. (1994), "The evolution of shopping center research: A review and analysis", Journal of Real Estate Research, Vol. 9, No. 1, pp. 5-32.

Forgey, F. A. and Goebel, P. R. (1995), "The use of locational factors by tenants in shopping centre space selection", Journal of Property Research, Vol. 12, No. 2, pp.149-156.

Gatzlaff. D. H., Sirmans, G.S. and Diskin, B.A. (1994), "The effect of anchor tenant loss on shopping center rents", Journal of Real Estate Research, Vol. 9, No. 1, pp. 99-110.

Hendershott, P. H., MacGregor, B. D. and Tse, R. Y. C. (2002), "Estimation of the rental adjustment process", Real Estate Economics, Vol. 30, No. 2, pp.165-183.

Hanna, M. E., Caples, S. C., Smith, C. A. and Rollins, C. P. (2007), "Factors impacting price for retail space in Houston", Journal of Economics and Economic Education Research, Vol. 10, No. 2, pp. 31-40. Harris, C. D. and Ullman, E. I. (1945), "The nature of cities". Annals of the American Academy of Political and Social Sciences, Vol. 24, No. 2, pp. 7- 17.

Hui, E. C. M., Yiu, C. Y. and Yau, Y. (2007), "Retail properties in Hong Kong: a rental analysis", Journal of Property Investment and Finance, Vol.25, No. 2, pp. 136-146.

Ibanez, M. R. and Pennington-Cross, A. (2013), "Commercial property rent dynamics in U.S. metropolitan areas: An examination of office, industrial, flex and retail space", Journal of Real Estate Finance and Economics, Vol. 46, No. 2, pp. 232-259.

Jones Lang LaSalle (2014): Wuhan Prime Retail. Wuhan: Real Estate Intelligence Service.

Kirkup, M. and Rafiq, M. (1994), "Managing tenant mix in new shopping centers", International Journal of Retail and Distribution Management, Vol. 22, No. 6, pp. 29-37.

Knight Frank (2011): China Retail Markets, Shanghai: Knight Frank.

Lam, A.C., (1995), "Tapping the retail market in China", China Business Review, Vol. 22, No. 5, pp.2328.

Liang, J. and Wilhelmsson, M. (2011), "The value of retail rents with regression models: a case study of Shanghai", Journal of Property Investment and Finance, Vol. 29, No. 6, pp. 630-639.

Mejia, L. C and Benjamin, J. D. (2002), "What do we know about the determinants of shopping center sales? Spatial vs non - spatial factors", Journal of Real Estate Literature, Vol. 10, No. 1, pp. 326.

Miceli, T. J., Sirmans, C. F and Stake, D. (1998), "Optional competition and allocation of space in shopping centers", Journal of Real Estate Research, Vol. 16, No. 1, pp. 113-126. 
Ordway, N., Bul, A. A. and Eakin, M. E. (1988), "Developing a visibility index to classify shopping centers", The Appraisal Journal, Vol. 56, pp. 233-242.

O'Roarty, B., McGreal, S. and Adair, A. (1997), "The impact of retailers' store selection criteria on the estimation of retail rents", Journal of Property Valuation and Investment, Vol. 15, No. 2, pp. 119-130. O'Roarty, B., McGreal, S. and Adair, A. (1998), "Clustering retailers by store space requirements: comparable evidence, retail function and rental value", Journal of Property Valuation and Investment, Vol. 16, No. 2, pp. 133-143.

Pashigan, B. and Gould, E. (1998), "Internalizing externalities: the pricing of space in shopping Centers", Journal of Law and Economics, Vol. 41, No. 1, pp. 115-142.

Shi, S., and Yang, A.S., (1998). "Retail roundabout", China Business Review, Vol. 25, No. 1, pp. 43-49 Sirmans, C. F. and Guidry, K. A. (1993), "The determinants of shopping centre rent", Journal of Real Estate Research, Vol. 8, No. 1, pp. 107-115.

Tay, R. S., Lau, C. K. and Leung, M. S. (1999), "The determination of rent in shopping centers: some evidence from Hong Kong", Journal of Real Estate Literature, Vol. 7, No. 2, pp. 183-196.

Vernon, P. (2012), "Shopping towns in Australia", The Journal of the Society of Architectural Historians, Vol. 22, No. 1, pp. 102-121.

Yuo, T. S. T., Lizieri, C., McCann, P. and Crosby, N. (2011), "Rental values in UK shopping malls". Urban Studies Journal Foundation, Vol. 48, No. 8, pp. 1667-1679.

Zheng, S. and Liu, H. (2003), "Economic theories of shopping center Planning and operation", Journal of Commercial Research, Vol. 278, No. 4, pp. 1-3. 
Table 2. Correlation of study variables

\begin{tabular}{|c|c|c|c|c|c|c|c|c|c|c|c|c|c|c|c|}
\hline & $\begin{array}{l}\text { Lnrent } \\
\text { (1) }\end{array}$ & $\begin{array}{l}\text { LnGFA } \\
\text { (2) }\end{array}$ & $\begin{array}{l}\text { AGE } \\
\text { (3) }\end{array}$ & $\begin{array}{l}\text { PSPACE } \\
\text { (4) }\end{array}$ & $\begin{array}{l}\text { CHEIGHT } \\
\text { (5) }\end{array}$ & $\begin{array}{l}\text { METRO } \\
(6)\end{array}$ & $\begin{array}{l}\text { MAINROAD } \\
\text { (7) }\end{array}$ & $\begin{array}{l}\text { CENTRAL } \\
\text { (8) }\end{array}$ & $\begin{array}{l}\text { RESIDENCE } \\
\text { (9) }\end{array}$ & $\begin{array}{l}\text { LSHAPED } \\
\text { (10) }\end{array}$ & $\begin{array}{l}\text { USHAPED } \\
\text { (11) }\end{array}$ & $\begin{array}{l}\text { ANCHOR } \\
\text { (12) }\end{array}$ & $\begin{array}{l}\text { RETAILMIX } \\
\text { (13) }\end{array}$ & $\begin{array}{l}\text { VRATE } \\
\text { (14) }\end{array}$ & $\begin{array}{c}\text { INCOME } \\
\text { (15) }\end{array}$ \\
\hline \multicolumn{16}{|l|}{1} \\
\hline 2 & 0.02 & & & & & & & & & & & & & & \\
\hline 3 & $0.38^{* *}$ & -0.16 & & & & & & & & & & & & & \\
\hline 4 & -0.12 & $0.63^{* *}$ & $-0.41 * *$ & & & & & & & & & & & & \\
\hline 5 & $0.77^{* *}$ & 0.15 & $0.31 * *$ & 0.01 & & & & & & & & & & & \\
\hline 6 & $0.48^{* *}$ & -0.12 & $0.33^{* *}$ & $-0.26^{*}$ & $0.29 *$ & & & & & & & & & & \\
\hline 7 & $0.33^{* *}$ & 0.06 & $0.25^{*}$ & 0.001 & $0.38 * *$ & 0.08 & & & & & & & & & \\
\hline 8 & $0.64 * *$ & -0.06 & $0.45^{* *}$ & -0.23 & $0.45^{* *}$ & $0.38 * *$ & 0.21 & & & & & & & & \\
\hline 9 & $0.52^{* *}$ & -0.11 & 0.16 & -0.14 & $0.37^{* *}$ & $0.45^{* *}$ & $0.31 * *$ & $0.39 * *$ & & & & & & & \\
\hline 10 & $0.24^{*}$ & -0.13 & 0.07 & -0.11 & $0.29 *$ & -0.03 & 0.13 & 0.21 & 0.18 & & & & & & \\
\hline 11 & -0.01 & 0.06 & -0.08 & 0.23 & 0.07 & -0.01 & -0.06 & -0.02 & -0.11 & -0.06 & & & & & \\
\hline 12 & 0.07 & $0.35^{* *}$ & 0.08 & 0.22 & 0.15 & -0.01 & 0.2 & -0.02 & 0.07 & 0.01 & 0.09 & & & & \\
\hline 13 & -0.07 & $0.4^{* *}$ & -0.05 & $0.30^{*}$ & 0.02 & 0.13 & 0.03 & -0.03 & -0.07 & -0.22 & 0.15 & $0.41^{* *}$ & & & \\
\hline 14 & $-0.31^{* *}$ & 0.14 & $-0.38^{* *}$ & $0.41 * *$ & -0.16 & -0.21 & -0.19 & $-0.27^{*}$ & -0.05 & -0.12 & 0.11 & -0.07 & -0.08 & & \\
\hline 15 & $0.40^{* *}$ & -0.23 & 0.25 & 0.00 & 0.16 & 0.05 & 0.01 & $0.43^{* *}$ & 0.23 & 0.13 & -0.08 & -0.18 & -0.12 & -0.1 & 1 \\
\hline
\end{tabular}

Note: ** and $*$ stand for significance at the 0.01 and 0.05 levels 